\title{
Tracheal Y-stent Implantation for Stenosis after Carina Reconstruction Surgery
}

\section{Karina Rekonstrüksiyon Cerrahisi Sonrası Gelişen Stenoza Trakeal Y-stent Uygulaması}

Mehmet Akif Özgül', Erdoğan Çetinkaya', Mustafa Çörtük², Binnaz Zeynep Yıldırım', Güler Özgül3, Fatma Esra Günaydın', Thierry Sibomona' ${ }^{1}$ Cemal Özçelik ${ }^{4}$ Alper Avcı'

\section{Abstract}

Primary tumors of distal trachea and tracheal carina without distant metastasis are extremely rare and surgical excision improves survival. Although various complications have been reported in case series, stenosis is rare on the anastomotic line and stent implantation. Herein, we present a 41 -year-old male case who presented with successful tracheal $Y$-stent implantation for stenosis after carina reconstruction surgery.

Key words: Stents, Trachea, Adenocarcinoma, Lung.

\section{Özet}

Distal trakea ve trakeal karinanın uzak metastaz olmaksızın primer tümörü çok nadirdir. Bu tür tümörlerin tedavisinde olgu serilerinde çeşitli komplikasyonlar bildirilmiştir. Ancak cerrahi anastomoz hattının stenozu ve bu nedenle yapılan stent implantasyonu bildirimi oldukça nadirdir. Biz 41 yaşındaki erkek hastada karina rezeksiyon cerrahisi sonrasında gelişen stenoz nedeniyle başarı ile trakeal Y-stent uyguladığımız bir olguyu sunduk.

Anahtar Sözcükler: Stentler, Trakea, Adenokarsinom, Akciğer.
Primary tumors of distal trachea and tracheal carina without metastasis are rare and surgical excision improves survival (1). Excision of these tumors requires surgical experience (2). Although complications have been reported in case series, stenosis is rare on the anastomotic line and stenting (2-4). To the best of our knowledge, cases of stenting for stenosis after carinal reconstruction are rare and our case is the first for in Turkey.

\footnotetext{
'Department of Chest Diseases, Yedikule Chest Diseases and Thoracic Surgery Training and Research Hospital, İstanbul, Turkey ${ }^{2}$ Department of Chest Diseases, Karabük University Faculty of Medicine, Karabük, Turkey

${ }^{3}$ Department of Chest Diseases, Bağclar Education and Research Hospital, İstanbul, Turkey

${ }^{4}$ Department of Thoracic Surgery, Çukurova University Faculty of Medicine, Adana, Turkey

'Yedikule Göğüs Hastalıkları ve Göğüs Cerrahisi Ĕ̆itim ve Araşıırma Hastanesi, Göğ̈̈s Hastalıkları Kliniği, İstanbul

${ }^{2}$ Karabük Üniversitesi Tıp Fakültesi, Göğüs Hastalıkları Anabilim Dalı, Karabük

${ }^{3}$ Bağcılar Eğitim ve Araşsırma Hastanesi, Göğüs Hastalıkları Kliniği, İstanbul

${ }^{4}$ Çukurova Üniversitesi Tıp Fakültesi, Göğüs Cerrahisi Anabilim Dalı, Adana
}

Submitted (Başvuru tarihi): 25.01.2016 Accepted (Kabul tarihi): 01.04 .2016

Correspondence (iletişim): Mehmet Akif Özgül, Department of Chest Diseases, Yedikule Chest Diseases and Thoracic Surgery Training and Research Hospital, İstanbul, Turkey

e-mail: aozgul1970@hotmail.com 


\section{CASE}

A 41 -year-old male was admitted to outpatient clinic with cough and dyspnea for 10 months. Computed tomography $(\mathrm{CT})$ revealed a mass lesion compressing trachea and tracheal carina (Figure 1). Fiberoptic bronchoscopy findings were normal, except the extrinsic tracheal and carinal compression. Biopsy and bronchial lavage were performed using fiberoptic bronchoscopy; however, it was non-diagnostic. An adenocarcinoma originating from trachea was diagnosed by thoracotomy. Since no metastasis was detected, the right and left upper lobes, the carina, and distal end of trachea were resected. The carina was reconstructed using end-to-end anastomosis between the trachea and intermediate bronchia (Figure 2). Adjuvant radiotherapy was administered. Two months after surgery dyspnea and cough restarted. Bilaterally diminished respiratory sounds were found in physical examination. Laboratory findings were normal. Although the chest $X$-ray was normal, partial obstruction of right main bronchus was detected on CT (Figure 3). Rigid bronchoscopy showed $90 \%$ obstruction of right main bronchus by complex stenosis and $70 \%$ obstruction of left main bronchus by mixed stenosis (Figure 4). Fibrotic tissue was removed and stenotic bronchi were dilated by progressively larger rigid tubes. 50\% and 30\% obstruction of the right and left bronchi respectively were present in the control rigid bronchoscopy so a $Y$-stent DumonTM (Novatech, La Ciotat, France) with a diameter of $15 \times 12 \times 12 \mathrm{~mm}$ and length of $2 \times 2 \times 1.5 \mathrm{~cm}$ was deployed without any complications (Figure 5 ). His symptoms diminished drastically after stenting. Five months later, the patient suffered from cough. Repeated bronchoscopy showed granulation tissue around the stent ridges. The stent was then removed and cryotherapy was performed on the granulation tissue. The patient is still asymptomatic during follow-up.

A written informed consent was obtained from the patient.

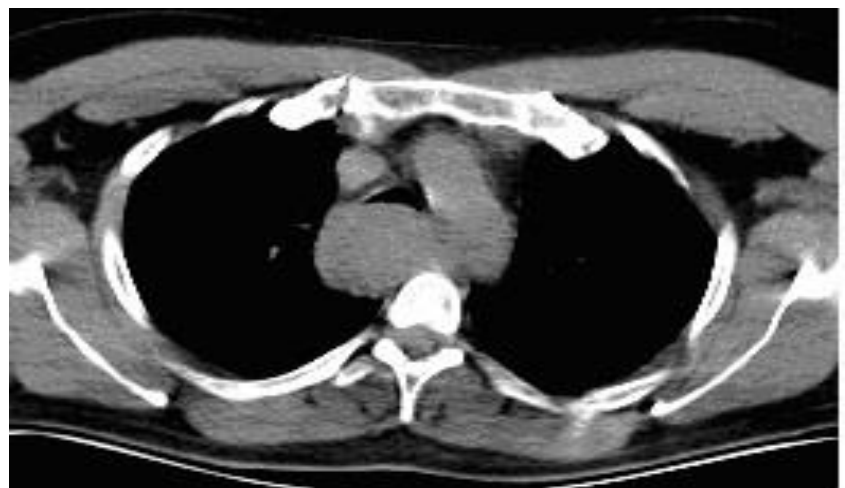

Figure 1: A thoracic tomographic view of the mass which compressed from trachea posterior at preoperative term
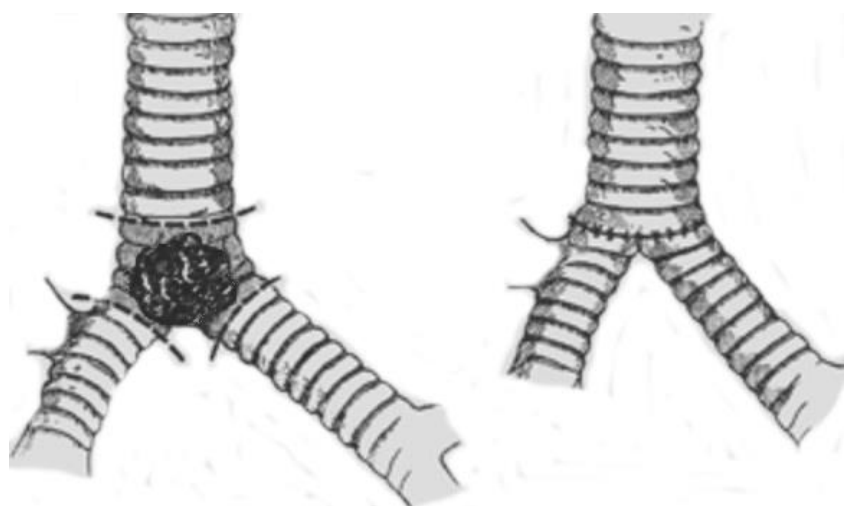

Figure 2: A diagrammatic image of the carina which was prevented at airways and was recreated during surgery

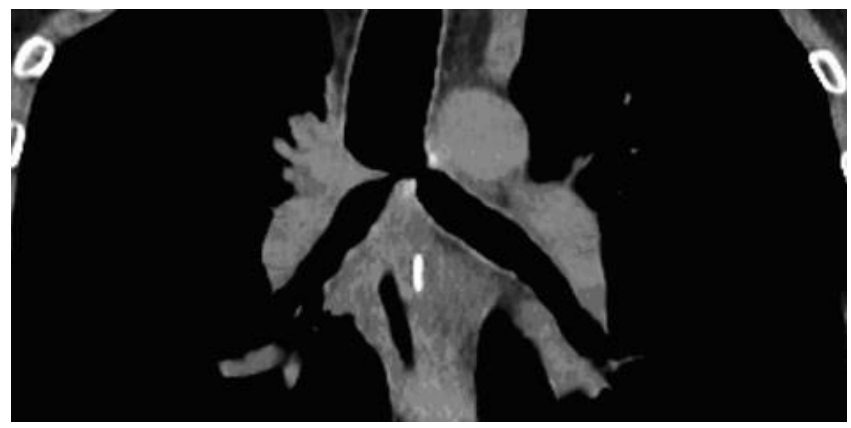

Figure 3: A thoracic tomographic view of stenosis at right main bronchi whose level was main carina level at postoperative term

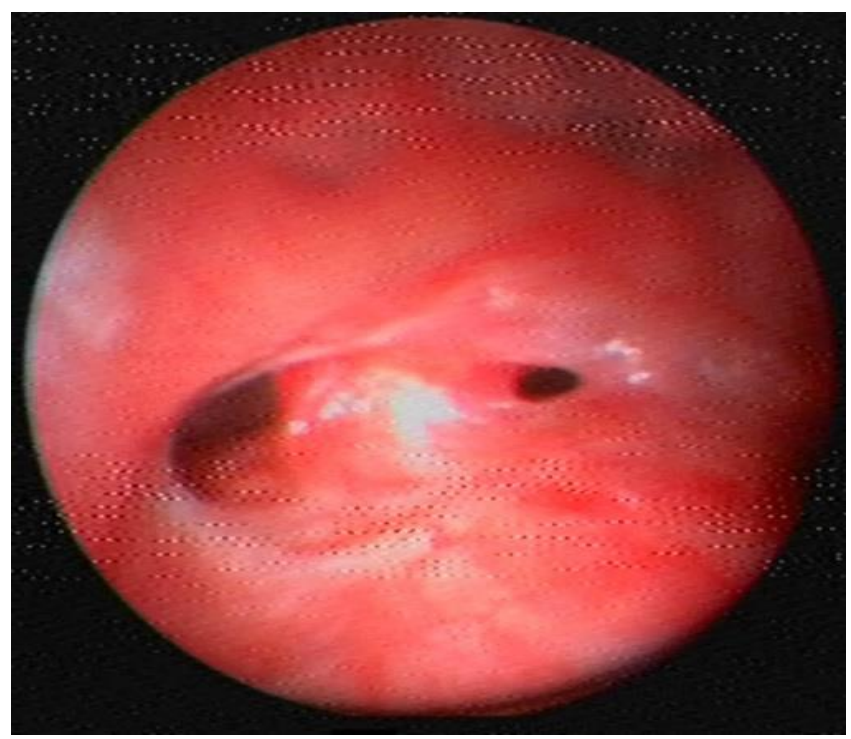

Figure 4: A bronchoscopic view of bilateral bronchial stenosis which was more obvious at right and carina level before stent use

\section{DISCUSSION}

Involvement of tracheal carina in non-small cell lung cancer (NSCLC) is considered T4 according to current TNM staging; stage 3B disease (5). In these cases, surgical excision of the tumor has acceptable mortality and morbidity rates and has been shown to improve survival in carefully selected patients (6). Resectable primary non- 
small cell tumors of distal trachea and tracheal carina are rare which require experienced surgeon and anesthesiologist (2). In a case series published by Shin et al. (6), younger patients with improved physical conditions were found to be more suitable for surgery. A significant, but acceptable rise in morbidity was also reported in the same series.

Various benign and malignant lesions can cause central airway stenosis. Benign causes include Wegener's granulomatosis, sarcoidosis, post-intubation stenosis and tracheobronchial stenosis secondary to surgery (7). Surgical resection can be used for the treatment of this benign stenosis. Alternative methods commonly used are argon plasma coagulation, laser, electrocautery, mechanical dilatation and cryotherapy during bronchoscopy (7). Promising results have been reported for the use of electrocautery and balloon dilatation in post-intubation stenosis (8). Stent implantation is usually preferred in posttransplant stenosis (11) or stenosis occurring after resection of tumors located near the tracheal carina, as in our case $(2,6,9,10)$.

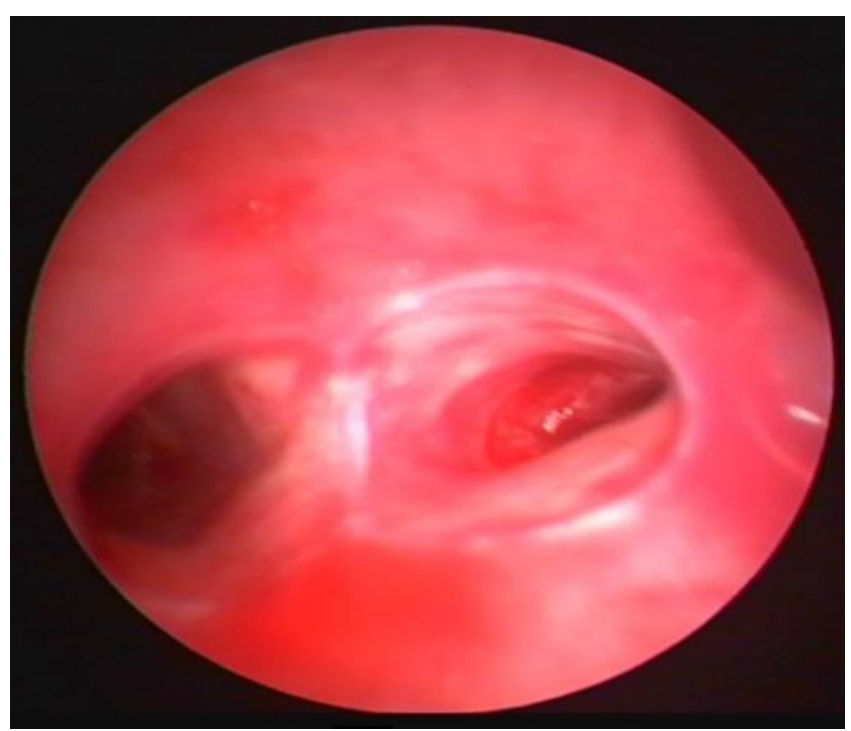

Figure 5: A bronchoscopic view of patency provided in main bronchus after stent use

Benign stenosis is basically either complex or web-like. Increased risk of recurrence is reported in complex stenosis, if only mechanical dilatation is used (8). Our case suffered from bilateral stenosis, where the right side was complex and the left side was mixed type. The risk of recurrence was considerably high; therefore stenting was preferred.

Silicon stents have been widely used in airway obstructions for various reasons (12). Few cases of stenting for stenosis after carinal resection and reconstruction have been reported to date. The first case of stenting for stenosis after carinal tumor resection was reported by Nomori et al. (3). In this case, expandable metallic stent (EMS) was used, granulation tissue developed during follow-up and the patient died at 24 months. Among the 30 cases presented by Shin et al. (2), three cases developed stenosis and stent was implemented in two. However, stent type and duration was not reported in the aforementioned study. In three series reported by Chida (9), Jiang (6) and Yamamoto (10); one of six cases, three of 41 cases, and two of nine cases required stenting, respectively. In these studies, Chida et al. (9) used metallic stents, Jiang et al. (6) used silicone stents, and Yamamoto et al. (10) used dynamic stents in four cases and silicone stents in two cases. Review of the literature revealed no other report on this patient group. In addition, there is no guideline or consensus on the safe duration for stents. Our patient complained of cough after five months and repeated bronchoscopy showed granulation tissue around stent ridges so the stent was removed.

Complications are common and can be severe in airway stents such as secretion retention, development of granulation tissue at the end of stent legs and migration, however; the latter two are seen less in $Y$ stents. Granulation tissue around stent ridges developed after five months and the stent was removed in our case.

Stents are made of different materials. The main classes of stents are silicone stents and metal stents. Silicone stents are easily retractable, but they also have increased risk of migration and secretion retention compared to metal stents. On the other hand, while metal stents have a low risk of migration and secretion retention, they are more difficult to remove if necessary $(12,13)$. We preferred silicone stent in our case to remove it easily later.

\section{CONCLUSION}

Silicon Y-stent was used in our case thanks to its easy removability. This is the first case of stenting for stenosis, after carinal resection reported in Turkey. The procedure is relatively safe under optimum conditions and improves symptoms drastically.

\section{CONFLICTS OF INTEREST}

None declared.

\section{AUTHOR CONTRIBUTIONS}

Concept - M.A.Ö., E.Ç., M.Ç., B.Z.Y., G.Ö., F.E.G., T.S., C.Ö., A.A.; Planning and Design - M.A.Ö., E.Ç., M.Ç., B.Z.Y., G.Ö., F.E.G., T.S., C.Ö., A.A.; Supervision - 
M.A.Ö., E.Ç., M.Ç., B.Z.Y., G.Ö., F.E.G., T.S., C.Ö., A.A.; Funding -; Materials - M.A.Ö., E.Ç., C.Ö., A.A.; Data Collection and/or Processing - M.A.Ö., E.Ç., M.Ç., C.Ö., A.A.; Analysis and/or Interpretation - M.A.Ö., E.Ç., M.Ç., C.Ö., A.A.; Literature Review - M.A.Ö., E.Ç., M.Ç.; Writing - M.A.Ö., E.Ç., M.Ç.; Critical Review - M.A.Ö., E.Ç.

\section{YAZAR KATKILARI}

Fikir - M.A.Ö., E.Ç., M.Ç., B.Z.Y., G.Ö., F.E.G., T.S., C.Ö., A.A.; Tasarım ve Dizayn - M.A.Ö., E.Ç., M.Ç., B.Z.Y., G.Ö., F.E.G., T.S., C.Ö., A.A.; Denetleme M.A.Ö., E.Ç., M.Ç., B.Z.Y., G.Ö., F.E.G., T.S., C.Ö., A.A.; Kaynaklar -; Malzemeler - M.A.Ö., E.Ç., C.Ö., A.A.; Veri Toplama ve/veya İşleme - M.A.Ö., E.Ç., M.Ç., C.Ö., A.A.; Analiz ve/veya Yorum - M.A.Ö., E.Ç., M.Ç., C.Ö., A.A.; Literatür Taraması - M.A.Ö., E.Ç., M.Ç.; Yazıyı Yazan - M.A.Ö., E.Ç., M.Ç.; Eleştirel Inceleme M.A.Ö., E.Ç.

\section{REFERENCES}

1. Gonfiotti A, Jaus MO, Barale D, Macchiarini P. Carinal resection. Thorac Surg Clin 2014; 24:477-84. [CrossRef]

2. Shin S, Park JS, Shim YM, Kim HJ, Kim J. Carinal resection and reconstruction in thoracic malignancies. J Surg Oncol 2014; 110:239-44. [CrossRef]

3. Nomori $H$, Horio $H$, Suzuki T. Postoperative airway stenosis and stent therapy in carinal reconstruction for lung cancer. Jpn J Thorac Cardiovasc Surg 1999; 47:522-5. [CrossRef]

4. Ishida I, Oura H, Niikawa H, Handa M. Noncircumferential tracheal resection with muscle flap reconstruction for adenoid cystic carcinoma. Gen Thorac Cardiovasc Surg 2012; 60:603-6. [CrossRef]
5. Ramnath N, Dilling TJ, Harris LJ, Kim AW, Michaud GC, Balekian AA, et al. Treatment of stage III non-small cell lung cancer: Diagnosis and management of lung cancer, 3rd ed: American College of Chest Physicians evidencebased clinical practice guidelines. Chest 2013; 143(5 Suppl):e314S-40S. [CrossRef]

6. Jiang F, Xu L, Yuan F, Huang J, Lu X, Zhang Z. Carinal resection and reconstruction in surgical treatment of bronchogenic carcinoma with carinal involvement. J Thorac Oncol 2009; 4:1375-9. [CrossRef]

7. Ernst A, Feller-Kopman D, Becker HD, Mehta AC. Central airway obstruction. Am J Respir Crit Care Med 2004; 169:1278-97. [CrossRef]

8. Jain B, Pasari N, Bajpai A, Chordiya R, Motiwale S. Role of electrocautery and balloon dilatation as treatment modality for patient of benign tracheal or bronchial stenosis. Indian J Thorac Cardiovasc Surg 2015; 31:1722. [CrossRef]

9. Chida M. Tracheocarinal resection and reconstruction. Nihon Geka Gakkai Zasshi 2013; 114:192-5.

10. Yamamoto K, Kosaba S, Ikeda T, Tokuyasu H. Evaluation of therapeutic method for malignant tumors involving the tracheal carina. Kyobu Geka 2001; 54:581-4.

11. Kapoor BS, May B, Panu N, Kowalik K, Hunter DW. Endobronchial stent placement for the management of airway complications after lung transplantation. J Vasc Interv Radiol 2007; 18:629-32. [CrossRef]

12. Dumon JF. A dedicated tracheobronchial stent. Chest 1990; 97:328-32. [CrossRef]

13. Peng $Z, X \cup S$, Li H, Sun C, Fu M. Metallic expandable stents in the management of malignant tracheal stenosis due to esophageal cancer with lymph node metastasis. Oncol Lett 2013; 6:1461-4. [CrossRef] 